\title{
The Tawagonshi Tale: Can Linguistic Analysis Prove the Tawagonshi Treaty to be a Forgery?
}

\author{
Harrie Hermkens, ${ }^{a}$ Jan Noordegraaf, ${ }^{\mathrm{b}}$ and Nicoline van der Sijs ${ }^{\mathrm{c}, *}$ \\ a) Tilburg \\ E-mail: harriehermkens@ziggo.nl \\ b) Vrije Universiteit Amsterdam \\ E-mail: j.noordegraaf@vu.nl \\ c) RUN / Meertens Institute \\ E-mail: Nicoline.van.der.Sijs@meertens.knaw.nl \\ Received 7 April 2013; accepted 18 June 2013
}

\begin{abstract}
In 1968 the American physician Lawrence G. van Loon published the text of the so-called Tawagonshi Treaty. This treaty, allegedly drawn up in 1613 between Dutch traders and Iroquois tribal leaders, is by some considered to be the first treaty made between Europeans and Native Americans. Others, however, believe it to be a fake. In this article we try to establish at what date the text was written, using linguistic analysis. Our conclusion is that the anachronisms and anglicisms in the Tawagonshi Treaty demonstrate without doubt that the text was forged in the twentieth century. Although it is plausible that Van Loon was the forger, we have only circumstantial evidence for this but no direct proof.
\end{abstract}

Keywords

Tawagonshi Treaty (1613); Iroquois; Dutch; seventeenth-century Dutch language; L.G. Van Loon

In 1968, Lawrence G. van Loon published an article that included the text of a treaty allegedly drawn up in 1613 between Dutch traders and Iroquois tribal leaders and written in seventeenth-century Dutch on two pieces of

* We would like to thank the following for help and information: Van Cleaf Bachman, Lunenburg, Nova Scotia; Clara van Beek, Jefferson, N.Y.; Nico van Campenhout, Stadsarchief Lokeren, Belgium; Jaap Jacobs, Dundee, United Kingdom; Rob Naborn, Philadelphia, Pa.; Roy Wright, Concordia University, Montreal, Qué. We thank Dieuwertje Kooij for her translation of this article. 
hide. The first words were "Hier op Tawagonshi" ("Here on Tawagonshi"). Tawagonshi was the name of a hill near Albany, N.Y. The text was signed by the Dutch traders Jacob Eelkens and Hendrick Christiaensz, and by four Iroquois, "chiefs of the Long House", Garhat Jannie, Caghneghsattakegh, Otskwiragerongh, and Teyoghswegengh. As no treaties were known to exist between Europeans and Native Americans from this early period of colonization, it was a sensational find. ${ }^{1}$ Soon after, in 1974, the text of the treaty was reprinted in The American Indian Reader. However, its authenticity was called into question, even before the text was published. In 1987, Charles T. Gehring, William A. Starna, and William N. Fenton subjected the text to thorough linguistic and historical research. Their article was the first publication to indicate that the treaty was a forgery. Given the fact that Van Loon was known to have forged other documents from the same period, they considered him the most likely forger. Most scholars agreed with their analysis, although their view was challenged by Vernon Benjamin in $1999 .^{2}$

In 2012, the issue returned to the limelight because of preparations being made by the Onondoga Nation and the Neighbors of the Onondaga Nation (NOON) to celebrate the four-hundredth anniversary of the "grandfather of all treaties" in August 2013. The commemoration has rekindled the debate

1 The first documented reference to the Dutch presence on the upper Hudson in Iroquois sources dates to 1678 ; see W.A. Starna, "Retrospecting the Origins of the League of the Iroquois," American Philosophical Society Proceedings, $15^{2}$ (2008), pp. 279-321.

2 Lawrence G. Van Loon, "Tawagonshi, the Beginning of the Treaty Era", The Indian Historian 1, pp 22-6; L. G. van Loon, "The Treaty of Tawagonshi", in Jeanette Henry (ed.), The American Indian Reader: History. Book Four of a Series in Educational Perspectives (San Francisco, Cal.: The Indian Historian Press, Inc. 1974), pp. 38-44; Charles T. Gehring, William A. Starna, and William N. Fenton, "The Tawagonshi Treaty of 1613: The Final Chapter", New York History 68 (1987), pp. 373-93; Charles T. Gehring and William A. Starna, "A Case of Fraud: The Dela Croix Letter and Map of 1634", New York History 66 (1985), pp. 249-61. See also Jan Noordegraaf, "The Dutch Language and Literature in the United States, 1624-1782", in Hans Krabbendam, Cornelis A. van Minnen and Giles Scott-Smith (eds.), Four Centuries of Dutch-American Relations, 16og-20o9 (Amsterdam: Boom Publishers, 2009), pp. 166-77; Nicoline van der Sijs, Cookies, Coleslaw, and Stoops: The Influence of Dutch on the NorthAmerican Languages (Amsterdam: Amsterdam University Press/Chicago, Ill.: University of Chicago Press, 2009), pp. 21-3; Vernon Benjamin, "The Tawagonshi Agreement of 1613: A Chain of Friendship in the Dutch Hudson Valley", Hudson Valley Regional Review 16, no. 2 (September 1999), pp. 1-20 (http://www.hudsonrivervalley.org/review/pdfs/hvrr_16pt2 _benjamin.pdf); see also his letter to the editor of 12 August 2012: http://blog.syracuse.com/ opinion/2012/08/historic_dispute_review_of_art.html. 
about whether or not the document published by Van Loon is a forgery. ${ }^{3}$ The question was debated in the Netherlands as well. ${ }^{4}$

In this essay, we can only rely on linguistic analysis in order to determine whether the text was written in the seventeenth century or at a later date, possibly by Van Loon, as the original document is nowhere to be found, and authenticity of paper, pen, ink or handwriting can therefore not be subjected to analysis. If the text originates from the seventeenth century, then it was most likely drawn up by the Dutch traders Eelkens and Christiaensz, who signed it. Little is known about these two men. Hendrick Christiaensz probably came from Cleves, a German town near the Dutch border. In the beginning of the seventeenth century he sailed as captain several times from Amsterdam to the Hudson River, where he established the trading post Fort Nassau in 1614. Jacob Jacobsz Eelkens sailed as supercargo on some of these voyages. Eelkens was born in Amsterdam in 1593. From 1600 to 1613 , he lived in Rouen in northern France, where his father represented the family's trading company. In Amsterdam, Hendrik Eelkens, uncle of Jacob Jacobsz Eelkens, took charge of business interests. After 1613, Jacob Eelkens made several voyages to the Hudson River. ${ }^{5}$ Eelkens only lived in the Netherlands till his seventh birthday. We do not know when and where he learned to read and write, but it seems improbable he learned more than the essentials. As to Christiaensz, it is unknown what education he received, but it certainly was not at a university level.

${ }^{3}$ Glenn Coin in Syracuse Post-Standard, 9 August 2012 (http://www.syracuse.com/news/ index.ssf/2012/08/400_years_later_a_legendary_ir.html); Charles T. Gehring and William A. Starna, "Revisiting the Fake Tawagonshi Treaty of 1613", New York History 93 (2012), pp. 95-101; James M. Odato in Albany Times Union, 1 January 2013 (http://www.timesunion .com/local/article/Is-wampum-proof-of-deal-4158853.php); Nicoline van der Sijs, "Indianen willen nepverdrag vieren", NRC Handelsblad, 21 August 2012, Wetenschapsbijlage p. 18; Nicoline van der Sijs, "De laatste spreker van Low Dutch'. L.G. van Loon vervalste de geschiedenis van het Nederlands in Amerika", Onze Taal 81 (2012), issue 10, pp. 282-3; Robert Venables, "An Analysis of 1613 Tawagonshi Treaty" (2012) (an elaborated version of an article published in 2009): http://www.onondaganation.org/aboutus/history_two_row_wampum .html.

4 In de Volkskrant of 3 January 2013, former diplomat Serv Wiemers called upon the Dutch government to honor the 1613 treaty. We responded with a letter to the editor published in de Volkskrant of 5 January 2013, as well as in the Internet magazine Neder-L (http:// nederl.blogspot.nl/2013/o1/tawagonshi-verdrag-is-vervalst.html).

5 Simon Hart, The Prehistory of the New Netherland Company: Amsterdam Notarial Records of the First Dutch Voyages to the Hudson (Amsterdam: City of Amsterdam Press, 1959), pp. 52-5. 
In this essay, we will first provide a short biography of Van Loon, discoverer (and potential forger) of the Tawagonshi document. Next, we will discuss the provenance and publishing history of the document and compare the different transcripts. Following that, we will on the basis of linguistic analysis try to establish at what date the text was written.

\section{Lawrence Van Loon}

Lawrence Gwyn Van Loon (1903-82) was an American physician with a lifelong passion for the history of the Dutch colonists in America and their descendants. It is possible that he was a direct descendant of Jan van Loon, who had emigrated from Liège in modern Belgium to New Netherland in the seventeenth century. In his youth, Van Loon's grandfather Walter Hill (1856-1925) taught him to speak the Mohawk Valley variety of Low Dutch (Leeg Duits), the term that over time had come to be associated with the variety of Dutch as it was spoken on the American East Coast. Van Loon was one of the last speakers of the "taol", as Low Dutch was popularly known - a fact of which he was very proud. ${ }^{6}$

To his fellow students at the University of Pennsylvania he was known as "Van". They asserted that Van Loon's main interest centered on the "windmills and tulips of Holland", the country he visited for the first time in 1930, and which many years later he still cherished a secret desire to "return to, at least once, before I die".7 "His medical career", in the meantime, "was preceded by diverse occupations and extensive tours to many foreign ports". ${ }^{8}$ According to family tradition, Van Loon had been a ship's doctor with the United States Merchant Marine before he specialized as a gynecologist. In that capacity he visited Hawai'i, and in 1930 he came to the Netherlands. There he met Grietje Prins (1903-83) from Aalsmeer, who became his wife on 25 August 1932. They had two children together, Tina and Jake, but their marriage ended in a divorce in 1962. For several decades Van Loon practiced as a physician in Reading, Pennsylvania; from the mid1950s he worked in Kalaupapa, Hawai'i. In 1968, he returned to the East Coast, where he worked for several government agencies for a number of

6 Van der Sijs, Cookies, Coleslaw, and Stoops, p. 18, pp. 42-4.

7 "Voor terug te gaone tenmenst voor een keer, bevoor ek gaon dood", he wrote in his diary Voetstappe achter weege ('Footsteps along the way').

8 Stated in The Clinic 1931, a publication of the Senior Class of the Jefferson Medical College in Philadelphia. 
years. Eventually he was more or less forced into retirement. He died on 7 November 1982, in Gloversville, N.Y., at the age of 79.

A compulsive worker, Van Loon not only set up his medical practice, but he also spent time studying the traces of the former Dutch presence on the East Coast. For a couple of years he worked as an archivist-translator for the Association of Blauvelt Descendants - an organization of descendants of the seventeenth-century Dutch immigrant Gerrit Blauvelt - founded in 1926. In this period he claims to have made several discoveries relating to the time that the Netherlands had settlements in North America. ${ }^{9}$

In 1938, Van Loon's work Crumbs from an Old Dutch Closet: The Dutch Dialect of Old New York was published in The Hague. Intended as the counterpart of the famous 1910 study by Professor J. Dyneley Prince on "the Jersey Dutch dialect", it became "one of the most cited sources on the structure of the Dutch dialect of upstate New York and its late survival". ${ }^{10}$ In 1939, Van Loon published two articles, written in Dutch, in Dutch journals. His study of the history of the Dutch in America resulted in the publication of an article entitled "Letter from Jeronimus de la Croix to the commissary at Fort Orange and a hitherto unknown map relating to surgeon Van den Bogaert's journey into the Mohawk country, 1634-1635" in The Dutch Settlers Society of Albany Yearbook, in 1940.

In 1939, Van Loon donated a number of documents - purportedly seventeenth-century Dutch manuscripts - to the New York State Library in Albany, N.Y. Most of the documents concerned the relationship between the Dutch and Native Americans. Until recently, the authenticity of these had not been investigated, in contrast to that of the De La Croix letter, of which it can be said with certainty that it is not a seventeenth-century document. ${ }^{11}$ The Tawagonshi document was not among the documents deposited in 1939 .

In the early 1940s, Van Loon recorded a series of "tales from the Hudson River and Mohawk Valley areas of New York spoken in Albany Dutch". One

9 Letter from Richard Amerman, editor of the journal de Halve Maen in October 1959 to the head of the Netherlands Information Service in New York (Dutch National Archives, The Hague, archive 2.05.118 (Code-Archief van het Ministerie van Buitenlandse Zaken 19551964), inv. no. 13687).

10 Anthony F. Buccini, "Swannekens Ende Wilden : Linguistic Attitudes and Communication Strategies among the Dutch and Indians in New Netherland", in Joanna C. Prins, Bettina Brandt, Thimothy Stevens, Thomas F. Shannon (eds.), The Low Countries and the New World(s): Travel, Discovery, Early Relations (Lanham, New York, and Oxford: University Press of America, 200o), pp. 11-28. Buccini is of the opinion that Crumbs "most likely presents falsified data" (p. 12), but he does not provide any specific examples.

11 Gehring and Starna, "A Case of Fraud". 
of the stories, published in 1980 under the title "Het Poelmeisie", is an old folk tale about a boy from Albany who is seduced by a mysterious and, of course, beautiful young woman. Van Loon claimed he himself had heard the story in 1915. A peculiar fact is that one particular line in his text is a clear allusion to a well-known and frequently reprinted Dutch children's book from 1891. The audio recordings of these tales are available in the Library of Congress. It is a strange experience for a listener today to hear Van Loon speak his variety of Low Dutch for seventy minutes. It should be noted that he never claimed that these stories would be a faithful representation of those he had heard in his youth: he only retold these tales for his own kyere ("children"). ${ }^{2}$

In the summer of 1948, Van Loon exchanged letters with William N. Fenton (1908-2005), a distinguished scholar of the Iroquois. Mentioning his interest in "the Mohawk dialect of the Iroquois", Van Loon wrote:

Whenever my sporadic "free hours" from an exclusive obstetric practice permit, I remain very much an enthusiast in the field, and for somewhat ethereal motives which at present are not important.

Among other things, Van Loon wondered how much time it would take to master the Iroquois language, and he noted furthermore: "I do have a 'bee in my bonnet' about a certain subject which I will relate to you only if you are prepared to hear a long winded story!" He assumed that Fenton would appreciate his "long existent but unenlightened enthusiasm" ${ }^{13}$ However, it was none other than Fenton who strongly opposed the publication of Van Loon's article in the journal de Halve Maen, in 1959.

While living on Hawai'i in the 196os. Van Loon put together an extensive "Läg Duits Opus" ("Low Dutch Opus"), as he mentioned to his Flemish correspondent Willem Pée (1903-86), professor of Dutch Linguistics at the University of Ghent. In this book, Voetstappe achter weege ('Footsteps along the way'), Van Loon recorded his opmerkinge en gedochte, his "comments and thoughts". On the one hand, he could give his "ego" free rein, on the other hand the book was intended as an extensive "literary monument" Van Loon had always regretted the fact that the speakers of Low Dutch left behind a scant written legacy. ${ }^{14}$ The complete title of the work, which was

12 Alice P. Kenney, Van Cleaf Bachman, and Lawrence G. van Loon, “'Het Poelmeisie': An Introduction to the Hudson Valley Dutch Dialect", New York History 61 (1980), pp. 161-85.

13 William Fenton papers, American Philosophical Society, Philadelphia. As far as we know, Fenton responded to these questions and remarks with just one polite though rather formal letter, dated 9 July 1948.

${ }_{14}$ L.G. van Loon to Willem Pée, 19 April 1970. Archief familie Pée, Stadsarchief Lokeren, Belgium. 
never published, is Voetstappe achter weege weezend schelferd meenenge end gedochtes geschreeve end zo tot prent gebrocht voor deest keer in de lage Duijts taol van oud Nieu York geschreeve op Kalaupapa in Hawaii, daer ook verblijve bijnao aoleen voetstappe ${ }^{15}$ The book contains a series of reminiscences, opinions, and comments distilled from the correspondence between Van Loon and the historian Van Cleaf Bachman during the years 1965-7; "The subject matter ranges from model railroading to contemporary politics, but the recurrent theme is the Low Dutch people and their language", Bachman stated. ${ }^{16}$

On 10 June 1965 Van Loon responded to an appeal from Dr. Van Cleaf Bachman (born 1939), author of Peltries or Plantations: The Economic Policies of the Dutch West India Company in New Netherland 1623-1639 (1969). In the preface to his book, Bachman, who made extensive use of original seventeenth-century Dutch manuscripts in his research, clearly showed that he was intrigued by the proposition that "Low Dutch, the descendant of the language of the New Netherlanders, was surviving with considerable vigor in many rural areas two hundred years after the English conquest". ${ }^{17}$ Thus, in April 1965, Bachman asked in de Halve Maen, the journal of the Holland Society of New York, for informants to help him to collect data about the nearly extinct Low Dutch language. Van Loon reacted by sending him a letter composed in Low Dutch, thus starting a long lasting and extensive correspondence on matters concerning this language, and Van Loon worked together with Bachman for a long period of time on a Low Dutch - English Dictionary that Bachman intended to compose, although personal circumstances forced Bachman to give up that project. ${ }^{18}$ While it was obvious he was critical of some of Van

15 "Footsteps along the way, being various opinions and thoughts written and printed for the first time in the Low Dutch language of old New York; written on Kalaupapa in Hawai'i, in which place the footsteps are also almost the only [things] that remain". In 1981, Van Loon donated his handwritten notebook to the New York State Historical Association Library. Gehring, Starna, and Fenton, "The Tawagonshi Treaty of 1613", p. 386.

16 Van Cleaf Bachman, "Introduction Low Dutch - English Dictionary”, unpublished typescript; Van Cleaf Bachman Papers, New York State Historical Association, Cooperstown, N.Y.

17 Van Cleaf Bachman, Peltries or Plantations: The Economic Policies of the Dutch West India Company in New Netherland 1623-1639 (Baltimore, Md. and London: The Johns Hopkins Press, 1969), p. viii.

18 For details see Jan Noordegraaf, "Vreemde woorden, valse vrienden. Over het woordenboek van het Leeg Duits (Low Dutch)”, Egbert Beijk et al. (eds.), Fons verborum, Feestbundel voor prof. dr. A.M.F.J. (Fons) Moerdijk aangeboden door vrienden en collega's bij zijn afscheid van het Instituut voor Nederlandse Lexicologie (Leiden: Instituut voor Nederlandse Lexicologie; Amsterdam: Gopher, 2009), pp. 73-83. 
Loon's opinions and observations, in an autobiographical outline in 1980 Bachman remarked that Van Loon "had the same romantic-nationalistic orientation as I". 19

\section{The Quest for the Original Treaty}

In 1959 de Halve Maen printed a call for manuscripts. In June, L.G. Van Loon submitted in reply an article on the Tawagonshi Treaty and a photostat of the original document. In September, the journal's editor Richard H. Amerman presented a copy of the photostat, Van Loon's transcript of it, and an English translation to the Netherlands Information Service in New York, with a request seeking to establish the authenticity of the manuscript. According to Amerman, Van Loon claimed that he had received the original document from

his relative, Major William C. van Loon, who had been an Indian agent for the Canadian government in the Canadian Mississauga reserve for years. ${ }^{20}$ Accompanying the document were a decorative axe and a beaded goatskin bag, the latter of which Van Loon gave away. The text was written on parchment, not on paper (italics added). ${ }^{21}$

Major Van Loon had been working as an "Indian agent" from 1903 until 1927, Amerman added. It was not mentioned - either here by Amerman or in later literature - whether any data concerning this Indian agent had been checked (did, for instance, William van Loon really exist?), or when Van Loon had actually obtained the document. So, the provenance of the original document has remained rather obscure. Editor Amerman had good grounds to insist that the photostat and the text of the transcript be thoroughly examined by various experts. Among these were two Dutch archivists.

First of all, via the Ministry of Foreign Affairs, Amerman's request was sent to Herman Hardenberg (1901-76), Chief Archivist of the Dutch National Archives in The Hague. Hardenberg examined the transcript, made some corrections, and retyped the text. Consequently, two copies can be found in the archives of the Foreign Affairs department:

19 Van Cleaf Bachman Papers, New York State Historical Association, Cooperstown, N.Y.

20 Note that in the 1968 article the name of this relative is not mentioned: Major Van Loon is just referred to as "an individual who was the agent on the Mississauga Reservation in Canada many years ago" (p. 24).

${ }^{21}$ In his 1968 article, however, Van Loon stated that "The document (...) was written upon two pieces of hide" (p. 24). 
one originating from the United States, with several handwritten corrections which we suspect were added in the Netherlands, possibly by Hardenberg, and a second, newly copied version which undoubtedly comes from Hardenberg. In October 1959, the archivist reported that he could not come to a reasoned judgment as to its legitimacy without having studied the original. He enclosed the transcript with some minor corrections, based on a different reading of the copy. ${ }^{22}$

Then, another Dutch expert was called for assistance. In July 1960, Amerman asked Dr. Simon Hart (1911-81), the distinguished municipal archivist of Amsterdam, for his opinion on the Tawagonshi text; in his wellknown 1959 study The Prehistory of the New Netherland Company, Hart had discussed Jacob Eelkens and Hendrick Christiaensz. A month later Hart replied that he had received the copy of "this exciting document". In his opinion "the wording and manner of writing of the document is conform to Dutch usage in the early $17^{\text {th }}$ century", but he had "never seen any documents which confirm the existence of this agreement in the year 1613". He speculated further, "I think that the original document (which according to my opinion must be a copy) is found in a book in which perhaps more interesting deeds are found ... I suppose that this book must be an account book or copybook of the Van Tweenhuysen Company or of the New Netherland Company"; this was an idea that excited him very much. Furthermore, Hart noted that "the form of registration in a book over the whole passage was unusually [sic]. It may also be possible that this copy was written on two pieces of parchment sewed together. I wonder how they could speak with the Indians". Because it was possible "that the date or the last cipher of the date was falsificated [sic]", he advised, "that the document from which the photo was made be examined". Hart also pointed out that the purported signature of Eelkens in the text did not agree with his authentic signature preserved in the Amsterdam Municipal Archives. He was not able to find a reliable signature of Christiaensz that could provide a basis for comparison.

Amerman immediately replied to Hart. It was now certain, he wrote, that the Tawagonshi document "is, at best, a copy". Thus the Editorial Committee of de Halve Maen did not think it was plausible that it originated from an account book of the Van Tweenhuysen Company. He regretted that "from ancient documents deposited in archives in The Netherlands" no supporting evidence of the existence of such a treaty could be found.

22 Dutch National Archives, The Hague, archive 2.05.118 (Code-Archief van het Ministerie van Buitenlandse Zaken 1955-1964), inv. no. 13687. 
However, examination would continue, Amerman stated, adding that "any developments will be promptly reported to you, for your keen interest in the matter is quite clear". ${ }^{23}$

In the United States, however, the debate about the authenticity of the treaty dragged on for many years, and eventually it reached an impasse. ${ }^{24}$ Van Loon never responded to the request to send the original, or at least a better copy. When his article had still not been published, he asked Amerman to return the copy before his article "Tawagonshi, the Beginning of the Treaty Era" eventually appeared in June 1968, in the first volume of the journal, The Indian Historian. ${ }^{25}$ It is not known what editorial or review procedures were followed at this time in this journal's history.

Given that Van Loon always refused to send the original document to Amerman for inspection by American and foreign reviewers, one may ask whether the original of the Tawagonshi treaty ever manifested itself. According to Van Loon, it did. As mentioned above, in the 196os Van Loon worked on an extensive manuscript, Voetstappe achter weege. In order to show traces of 'onze verdweene Läg Duits' vooroudez en hullies' daoge van glory" ("our lost Low Dutch ancestors and their days of glory"), as well as the "voetstappe van de ook longverdwene welde" ("footsteps of the also long-lost savages"), the text of the Tawagonshi Treaty had also been included in this work, "gecontrafeyt van die oud document", i.e. "copied of the old document". According to a later comment written below the text, Van Loon gave the "oorspronklik stuk väl" ("the original piece of hide") to two Onondaga chiefs in 1978, Leon Shenandoah and Irving Powless, ${ }^{26}$ "voor behouding tot Syracuse, N.Y., de hoofdoffis van de Rotinonghsijonnie" ("for safekeeping in the Syracuse, N.Y., headquarters of the People of the Longhouse"). Probably they made photostats of this "original piece of hide"; when one year later a number of sachems and spokesmen for the Iroquois League visited Europe, they had in their luggage, as De Soeten noted, "een kopie" ("a copy") of the Tawagonshi Treaty. ${ }^{27}$

23 Stadsarchief Amsterdam, archive no. 883 (Simon Hart Papers), inv. no. 2.

24 See Gehring, Starna, and Fenton, "The Tawagonshi Treaty of 1613", pp. 380-3.

25 It is not clear to us whether Van Loon had adapted the text of his article for this publication.

26 According to Irving Powless Jr., however, "he gave it to the Onondaga in 1972" (cf. James M. Odato in Albany Times Union, 1 January 2013). Benjamin, "Tawagonshi Agreement", p. 12, remarks that the hides "disappeared after van Loon gave them to the Onondaga shortly before the 1959 Holland Society review".

27 Dick de Soeten, Als de schildpad sterft. Het epos van een indiaans bondgenootschap (Amsterdam: Gopher BV, 2008), pp. 95-6. 
In November 1980, the fourth Russell Tribunal took place in Rotterdam, which was devoted to the infringement of the rights of the indigenous peoples of North and South America. Dutch political activist and publicist Ton Regtien (1938-89) reported on it daily in the communist newspaper De Waarheid. He also interviewed Onondaga Chief Oren Lyons (born 1930), the spokesman for the Iroquois League. ${ }^{28}$ In the detailed oral version of the interview, recorded on tape, Lyons can be heard stating: "we also have documents dating back to 1613", even though these were "difficult to read". Regtien also noted that Lyons handed him "an old document from April 1613, which for centuries had been carefully preserved by the Indians". As Regtien himself could not decipher the seventeenth-century text, ${ }^{29}$ three employees of the Amsterdam Municipal Archives were so kind as to analyze it; they published a transcript of it in De Waarheid of 28 January $1981,{ }^{30}$ along with a picture of the treaty document that Lyons had provided. Thus, the text became part of the international political debate. However, when Lyons spoke before the Russell Tribunal about the "Haudenosaunee case", i.e. the case of the Iroquois, he did not, at least according to Regtien's report, mention the Tawagonshi Treaty. ${ }^{31}$ Incidentally, Regtien also remarked that the document that Lyons had with him was the "original" version of the treaty, a statement we could not verify. Note, however, that in his articles, Regtien never used the word "huid" ("hide"), but always referred to the "document" or the "manuscript". We assume that what was handed to him was just a photocopy of the "original".

So, as it appears from the two cases presented above, copies of the document were circulating among the Indians after 1978. We could add one more example: in the beginning of the 1980s, during one of his visits to the Mohawks, one of the Dutch organizers of the Russell Tribunal, Dick de Soeten (born 1937), received a typescript copy of the "Tawagonshi Treaty" from two Mohawk representatives of the Long House, Sakakwenonkwas

28 Ton Regtien, "De macht en de vrede moeten terug in de handen van de mensen". [Interview with Chief Oren Lyons]. De Waarheid. Volksdagblad voor Nederland, 1 December 1980 (posteditie).

29 Ton Regtien, "Nederlanders sloten verdrag met Indianen". De Waarheid, 1 December 1980 (posteditie). Several years later Regtien returned to the subject in an article "Soo langh 't gras groen is". De Waarheid, 5 July 1984 (posteditie).

30 Gerrit Kouwenhoven, Anneke van Veen, and Jaap Verseput, "Voor soolangh 't gras groen is ..."', De Waarheid, 28 January 1981 (posteditie). Regtien sent an English translation of the treaty to "our brave brothers and sisters in North America, the brave tribe of the Iroquois".

31 Internationaal Instituut voor Sociale Geschiedenis, Amsterdam, Ton Regtien Papers. 
(Tom Porter) and Kanasatakeh (Loran Thompson), although De Soeten could not at all place the document historically. ${ }^{32}$

Presently, a photostat copy of the Tawagonshi Treaty, deposited in 1959 by John Howard Haring, one of many specialists consulted by de Halve Maen, is available in the New York State Library. ${ }^{33}$ This must be a copy of the photostat of the Tawagonshi Treaty that was sent to the editors of $d e$ Halve Maen by Van Loon. ${ }^{34}$ The copy in the State Library was included in the 1987 article by Gehring, Starna, and Fenton and seems to be identical to the picture that was published in De Waarheid in 1981. The ultimate source of the copy must have been Van Loon himself.

Van Loon's 1968 article states in a footnote: "The photostat [not the original] of the Tawagonshi Treaty is in the possession of Doctor Van Loon; a copy is in the archives of the American Indian Historical Society. No other record has been found thus far". Unfortunately, the copy in question has never been found. But where is the original? And what was it written on? In his 1968 article, reprinted in 1974, Van Loon reports that the text is "written on two pieces of hide". According to an entry in his diary Voetstappe achter weege, Van Loon gave these hides to two Onondaga chiefs in 1978. Informants told Gehring and his co-authors that the document "is in the possession of the Grand Council at Onondaga"; however, they indicated "that it is written on paper, not on skin or hide". ${ }^{35}$

As we pointed out above, documents in the archives of the Dutch Ministry of Foreign Affairs note that in 1959 Van Loon informed Amerman that the text was written on parchment and not on paper. Amerman added that "in an article he wrote, Van Loon states that the dimensions of the piece amount to around $7^{1 / 2} \times 13$ inches $(19 \times 33 \mathrm{~cm})$ when both halves are placed next to each together along the center line; it is possible that they used to be sewn together along this line, or that they are pages of a book". ${ }^{36}$

The question concerning what exactly the text was written on is intriguing: although parchment is made of hide, it requires elaborate treatment, while the term hide seems to imply some sort of roughly treated cowhide or deerskin - why not use the conventional English term "parchment"

\footnotetext{
32 De Soeten, Als de schildpad sterft, pp. 96-7.

33 New York State Library SC16677. See Gehring, Starna, and Fenton, "The Tawagonshi Treaty of 1613", pp. $381-2$. Fred Bassett from the NYSL noted the following: "In regards to the photostat copy of the Tawagonshi Treaty document, our accession log book indicates we received it as a gift from J. H. Haring in November 1959, but did not officially add it to our holdings until 1965." (e-mail 1 November 2012).

34 Richard Amerman to Simon Hart, 18 August 1960.

35 Gehring, Starna, and Fenton, “The Tawagonshi Treaty of 1613", p. 386.

36 Cf. Van Loon, "Tawagonshi, Beginning of the Treaty Era”, p. 24.
} 
otherwise? And where did the material come from? If it actually is parchment, the Iroquois cannot have been the suppliers, as parchment must have been brought from Europe. It seems implausible, though, that Dutch traders in America in 1613 had the time and means to process hides into parchment. Thus, Eelkens and Christiaensz probably had brought a piece of parchment with them. Then there is the issue of preservation: in view of the American climate and the changes of territories of the Iroquois, it is unlikely that hides could have been preserved for four centuries. In principle, when treated carefully, parchment keeps quite well. The question is whether the same is true for treated hides.

Be this as it may, the quest for the original document, which has been lingering on for some 50 years, can be considered to have definitively ended by now. Robert Venables, who "had the privilege of examining the treaty on several occasions", concluded in 2012 that the source of the handwritten copy he inspected is "now lost". He elaborated:

The handwritten copy covers two pages that were originally in a notebook that I believe dates from the nineteenth or twentieth century. The transcript, in ink, is in seventeenth-century Dutch. The two-page transcript was collected and translated by L.G. Van Loon, M.D. [...] Each of the two pages is approximately $5.5 \times 7.0$ inches. The pages are mounted within a wooden frame. (italics added).

Venables did not refer to any hides or skin, but he mentions "parchment or high quality paper" ${ }^{37}$ It could therefore be concluded that Van Loon provided the Onondaga chiefs in 1978 with this paper (or parchment) version of the treaty, not with the "oorspronklik stuk väl ("the original piece of hide"). ${ }^{38}$

The handwritten copy examined by Venables may have been the source of all photostats and transcripts brought into circulation from 1959 onwards. The next section provides an overview of the transcripts that were available to us. Thereafter, we will present a linguistic analysis of the text of Tawagonshi document.

\section{Transcripts of the Tawagonshi Document}

As indicated above, different transcripts of the Tawagonshi document exist. The three oldest transcripts were all made by Van Loon. The oldest

\footnotetext{
37 Venables, "An analysis".

38 Cf. Robert Venables (s.d. [2009?]), "The 1613 Treaty”, p. 1. (http://honorthetworow.org/ wp-ontent/uploads/2012/o1/VenablesonTwoRow-1.pdf.)
} 
transcript, henceforth "Transcript A", can be found in the archives of the Dutch Ministry of Foreign Affairs. ${ }^{39}$ This is the transcript that was sent to the Chief Archivist of the Dutch National Archives in 1959. For the text see Appendix 1. The second transcript ("Transcript B") comes from Van Loon's Low Dutch diary Voetstappe achter weege and dates from around 1966. Two years later, Van Loon published the text in his article in The Indian Historian ("Transcript C"), ${ }^{40}$ to which he added an English translation (Appendix 2). On 28 January 1981, Gerrit Kouwenhoven and his colleagues of the Amsterdam municipal archives made a transcript that was published in $D e$ Waarheid ("Transcript D"). In their article from 1987, Gehring, Starna and Fenton include a transcript of the text ("Transcript E"), which differs in some respects from that published by Van Loon in 1968. They also provided a translation of the document, with some small deviations from Van Loon's translation (see Appendix 2). In 2008, Dick de Soeten published a transcript ("F"), ${ }^{41}$ without referring to the 1981 article in De Waarheid or the 1987 article by Gehring, Starna, and Fenton. De Soeten's goal, though, was not to create a scientific, diplomatic transcript, which is why we leave this transcript out of consideration here. His transcript does correspond roughly to the other transcripts, but it contains several deviations. The most noticeable of these are that De Soeten writes per brava instead of per breva, and that he dates the treaty to 24 April instead of 21 April 1613. Lastly, we have made a transcript of our own ('G'). There are thus seven slightly different transcripts in circulation $(A-G)$. The variants used in the different versions are listed in Appendix 3 below.

It is striking that by far the largest number of deviations is found in the 1966 text. How can this be explained? Did Van Loon in 1966 make a new transcript without the existing transcript at his disposal? This turns out not to have been the case, because in his introduction he claimed that he had "copied the text from the old document". Was the rather different 1959 version then not a correct copy of the original? Further examination of the 1966 variants reveals that they consistently correspond to Low Dutch, the language in which Voetstappe achter weege was written. Characteristics of Low Dutch are the omission of the final $-n$ (wilde, de, verclaere, Participante,

39 Dutch National Archives, The Hague, archive 2.05.118 (Code-Archief van het Ministerie van Buitenlandse Zaken 1955-1964), inv. no. 13687.

40 The text was reprinted in Henry, The American Indian Reader, pp. 38-44. In this edition the transcript of the treaty is lacking: only an English translation is given; the brief bibliography is also not included.

${ }^{41}$ De Soeten, Als de schildpad sterft, pp. 69-98. 
beloove, hebbe, brenge, eyghe, individueele, helpe, moete, beloove, verruyle). Also typically Low Dutch are the spellings of vaodem for vaedem, neereng for neeringh and ' $t$ instead of $t$ '. Besluit for besluyt, ook for oock, grondstukken for grondstucken, gebrek for gebreck, and zilverketting for silver ketting also indicate Low Dutch influence.

It is difficult to answer the question why Van Loon introduced so many Low Dutch spellings in his 1966 transcript: was he trying to demonstrate that the Tawagonshi Treaty was a kind of precursor of Low Dutch? He compiled the Voetstappe achter weege, after all, with the explicit purpose to establish a monument for the Low Dutch language.

In addition, Van Loon's transcripts from 1959 and 1968 are not completely identical, which suggests that he made some changes over the years, maybe at the suggestion of one of the reviewers (Amerman, Hardenberg, Hart). However, the 1968 text is not a corrected version of the 1959 text as it features several errors that are not present in the text from 1959. Some of these (to ondersoecken - instead of te ondersoecken "to research") may have easily been made by the typesetter. Others are surprising, for example $\$$ accordert: the first symbol (\$) is an abbreviation symbol of ver-; in 1959 he wrote g'accordeerdt (while the 1966 version features the correctly written veraccoordert, so the abbreviation was known to him).

The variants made by others (D-F) show only slight differences from each other. These can easily be explained by the fact that the available photocopy was of very low quality. As far as we can ascertain, all transcripts are based on the same photocopy (or a copy of that), which is located in the New York State Library archives in Albany, N.Y.

\section{A Linguistic Analysis of the Tawagonshi Document}

There are two possibilities: the document was written by Eelkens and Christiaensz in the beginning of the seventeenth century or it was forged, probably in the twentieth century, by Van Loon. In order to prove a forgery, we have to look for anachronisms in the text. ${ }^{42}$ To achieve this, we would ideally have a research environment to our disposal in which we could analyze digitally an extensive corpus of texts from the beginning of the seventeenth century, including documents from archives, and compare these

\footnotetext{
42 Some anachronisms are mentioned in Gehring, Starna, and Fenton, "The Tawagonshi Treaty of 1613 ", p. 385 .
} 
with later texts. However, this research environment does not yet exist. ${ }^{43}$ For this reason, we have checked the age of the forms and meanings using the Woordenboek der Nederlandsche taal (WNT - "Dictionary of the Dutch language", accessible on the internet: gtb.inl.nl), the text corpus Digitale Bibliotheek voor de Nederlandse Letteren (DBNL - "Digital Library for Dutch Literature”, www.dbnl.org), Van der Sijs, Chronologisch woordenboek, and the etymologiebank ("etymology bank", www.etymologiebank .nl). We have also used the search engine Kronos (www.zoekkronos.nl), which browses texts on a large number of websites, and displays the forms (not word combinations) found in chronological order. In order to evaluate to what extent forms can be considered to be anglicisms, we have also consulted the Oxford English Dictionary (OED).

\section{Spelling}

The spelling of the treaty is quite consistent and in principle does not conflict with other texts from the seventeenth century. Striking, nevertheless, is the consistent spelling of vowels $e$ and $o$ as double vowels $e e$ and $o o$ in open syllables: coomen, alsmeede, overeengecoomen, belooven, soolangh, weedersijdts, noodigheden, meening verschil, deese, onderteekent. This spelling is known to have been used in the seventeenth century, but indicates that the writer was well-educated - especially given the consistency with which it is used here. We would not expect Eelkens en Christiaensz to have used this spelling. It happens to be the spelling Van Loon used in his Low Dutch diary Voetstappe achter weege.

Compounds were sometimes written as separate words in the seventeenth century, so meening verschil ("disagreement"), and coop verdragh ("purchase agreement"), are conceivable spellings (but see below for both forms); the spelling of the derivation voor Reght ("privilege"), on the other hand, is conspicuous and could indicate an anglicism.

\section{Grammar}

The text includes several conspicuous grammatical forms. Firstly, there are archaic forms and typical written language forms. See Appendix 4 for an enumeration. Then there are several mistakes in terms of gender.

\footnotetext{
43 It will be built in the coming years within the project Nederlab, with a substantial grant from the Netherlands Organization of Scientific Research (NOW); see www.nederlab.nl.
} 
Finally, there are some other grammatical mistakes: ondergeschreeven ("undersigned") instead of ondergeschrevenen or onderschrevenen; the use of daeraen gaende ("thereupon") instead of dienaangaande; and the expression ende kenniss der waerheydt ("and knowledge of the truth"), which should either be ende tot/als kenniss der waerheydt ("and as knowledge of the truth"), or in/ter kennisse der waerheydt ("in knowledge of the truth").

One would not readily expect people such as Eelkens and Christiaensz, who were not highly educated, to have used archaic and formal language forms. These forms would rather suggest that the Tawagonshi Treaty was drawn up in the twentieth century, on the basis of older examples. The mistakes in gender and grammar are typical for those who have learned Dutch as a second language (like Van Loon). The omission of the relative pronoun is an anglicism, as it was not known in seventeenth-century Dutch.

The combination of archaic forms and mistakes in gender in one and the same text seems to indicate strongly that the treaty did not originate in the seventeenth century.

\section{Anglicisms}

There are at least thirteen words or word combinations that can only be explained as anglicisms, see Appendix 4. They were not known in seventeenth-century Dutch, which at that time had undergone hardly any English influence. ${ }^{44}$ Interestingly, some of the anglicisms were not known in seventeenth-century English, but came into use at a later date. On the whole, the use of anglicisms conclusively demonstrates that the treaty was not written in the seventeenth century.

\section{Anachronistic Word Forms or Meanings}

Ten word forms and nine meanings used in the Tawagonshi Treaty did not exist in seventeenth-century Dutch, but do occur in modern Dutch. ${ }^{45}$ Some of these were first recorded in Dutch in the eighteenth century, some in the nineteenth century, and some were first found even later. This can only be explained if the text was written in the twentieth century, and therefore a forgery. It is, incidentally, possible that - in the future, as more old texts

\footnotetext{
44 Nicoline van der Sijs, Chronologisch woordenboek: de ouderdom en herkomst van onze woorden en betekenissen (Amsterdam: Veen, 2001), pp. 273-6.

45 Some anachronisms are mentioned in Gehring, Starna, and Fenton, "The Tawagonshi Treaty of 1613 ", p. 385 . Our default source is the WNT.
} 
become digitally available - some word combinations or meanings will turn out to have been in use around 1613 after all. However, this will not alter the general conclusion that the text is a forgery, as the number of demonstrated anachronisms remains large.

\section{Concluding Remarks}

The anachronisms and anglicisms in the "Tawagonshi Treaty" demonstrate without doubt that Eelkens and Christiaensz cannot have been the authors of the text: it was forged in the twentieth century. The large number of grammatical errors (8), anglicisms (13) and anachronisms (19) in the short stretch of text of the treaty - comprising only 315 words - is striking. This considerable number suggests it is unlikely that the forger used an existing old text as a model. In order to be sure, now that so many texts become digitally available, we put the transcript through several plagiarism checkers, but this did not yield any results. We also searched for separate word combinations in Google Books, again with no results. It is equally unlikely that an existing original was transcribed by a later copier with insufficient schooling; if such a copier aimed for a faithful copy, he would certainly have introduced spelling mistakes, whereas none are found in the transcript. If it was the copier's aim to translate the document, he would not have used words and meanings that never existed together in the same timeframe. It is also unlikely that he would have used seventeenth-century spelling.

The most important question, meanwhile, is still unresolved: was Van Loon the forger, or was he not? There is enough circumstantial evidence to support a "charge": Van Loon was the "discoverer" of the treaty, he remained rather vague about its origin, and he had been trying to peddle his manuscript since 1959. But are there any linguistic arguments to attribute the forgery on him?

It is clear from the text that the forger must have known both Dutch and English, and that he must have had some knowledge of seventeenthcentury Dutch. Van Loon met these requirements. Historian Van Cleaf Bachman, who worked together with Van Loon for years, observed that Van Loon mixed all sorts of language varieties together in a manner consistent with the impression of the forger we get from the document. ${ }^{46}$

\footnotetext{
46 Van der Sijs, Cookies, Coleslaw, and Stoops, pp. 43-4. Cf. Gehring, Starna, and Fenton, "The Tawagonshi Treaty of 1613", p. 392: "He knew Dutch, modern and seventeenth-century forms, very well, if not perfectly".
} 
If similarities between the text of the treaty and the Low Dutch that Van Loon used in Voetstappe achter weege were found, this would prove beyond doubt that Van Loon was the forger: at that time Van Loon was, after all, "the last speaker of the 'taol". There are indeed some similarities: apart from the spelling $e e$ and $o o$ (see above), some meanings in the treaty can be derived from Low Dutch, and the verb order in subordinate clauses corresponds to that in Low Dutch: in Dat [...] sal toegelaeten worden ("that [...] shall be allowed") and dat [...] sal moeten gebraght worden ("that [...] shall have to be brought") the past participle is located between the finite verb and the main verb, while in modern Standard Dutch the past participle is located either at the end or before the finite verb. However, these indications are unfortunately not strong evidence, since we know very little of the extent of Van Loon's knowledge of Low Dutch: the Voetstappe achter weege are deposited in the New York State Historical Association Library and we have only a few selected copied pages, including the chapter on Tawagonshi, at our disposal.

Contributing to the case against Van Loon, however, is that other document forgery can be ascribed to him with absolute certainty: a purported letter by Jeronimus de la Croix, who took part in the 1634 expedition into the Mohawk Valley, led by Harmen Meyndertsz van den Bogaert, from 19 December $1634 \cdot{ }^{47}$

Since it has been established that this letter was forged by Van Loon, it is worthwhile to see to what extent language errors in the letter correspond to mistakes in the Tawagonshi Treaty. Like the Tawagonshi Treaty, the De La Croix letter also contains word forms that did not exist in the seventeenth century, such as plattelandt ("countryside"), verzaghtigen ("to soften"); meanings that did not exist in the seventeenth century, such as huydt ("bark"); anglicisms, such as gebruik maken van ("make use of"); mistakes in word gender, such as een goedt afstand ("a good distance"), een schrale bordt ("a meagre plate"), ons tabac ("our tobacco"); mistakes in grammar, such as $u$ instead of gij ("you", as subject form); and archaic forms, such as ende ("and"). Furthermore, plural forms and verb forms appear regularly written without a final $-n$ as in hadde ("(they) had"), pampiere ("papers"), hande ("hands"), as was the custom of uneducated writers in those days, but a practice that is also characteristic of Low Dutch.

47 L.G. van Loon, "Letter from Jeronimus de la Croix to the Commissary at Fort Orange and a Hitherto Unknown Map Relating to Surgeon Van den Bogaert's Journey into the Mohawk Country", The Dutch Settlers Society of Albany Yearbook 15 (1939-40), pp. 1-9. Cf. Gehring and Starna, "A Case of Fraud". 
The errors in the fabricated De La Croix letter are similar to those in the Tawagonshi Treaty. Spelling and choice of words in the letter deviate from that in the treaty, but that is understandable: they are different types of text and in the letter Van Loon was able to take the text from Van den Bogaert's diary as an example. That he did so is demonstrated by the fact that both texts, for instance, feature the very unusual ey as spelling for $i j$, as in sneyden ("cut") and meynheer ("sir").

We end with a hypothesis that cannot be verified, but if, as seems highly likely, Van Loon is indeed the forger, and if he indeed did not use an existing example, then how did he come by his text? On account of the word usage, the anglicisms and the mistakes in grammar, it seems to be quite possible that he wrote the text in Low Dutch first, before adapting spelling and the like to seventeenth-century Dutch. Perhaps Van Loon in this way tried to emphasize the bond between seventeenth-century Dutch and Low Dutch, a language he loved so much. To make it all plausible, he added metaphors that were associated with the Native Americans (as long as the grass is green, silver chain) and well-known references to the history of the Native Americans, such as seewant and the Treaty of Amity and Friendship from 1682 .

In his Voetstappe Van Loon concluded his six-page chapter on the Tawagonshi Treaty with the evocation of what looks like a scene from a true gothic novel:

Koome de geeste van Garhat Jannie, Caghnegsattakegh, Otskwirageronh, end Teyoghswegengh zoo nou en dan op nen nacht-van-volle-maon uit de boome van de Twagonshies' kreupelbos, zoo te bekijke de plaots waor zoo veel blongriks had plaats geneem - toe wij jong were - toe wij de baoze were?

Gaone Eelkens en Christianssen nen schootje drooye in hullies begraofplaats, waor dat dan ez, op needer een-end-twätigste van April? Het ez te twyfele. ${ }^{48}$

Agayondosera Yondennaze, Ratiyats.

So, as it happens, Van Loon's final words on this matter were phrased in Iroquois and borrowed from The Iroquois Book of Rites published in 1883 by Horatio Hale (1817-97). A heading in this book is titled "Okayondonhsera

\footnotetext{
48 "Will the ghosts of Garhat Jannie, Caghnegsattakegh, Otskwirageronh and Teyoghswegengh appear from the trees of the Tawagonshi undergrowth, now and again, at night, in the full moon, to look at the places where so many important things happened - when we were young - when we were the boss? Will Eelkens and Christianssen turn over in their graves - wherever those may be - on 21 April? It is unlikely".
} 
Yondennase", which Hale rendered as "The ancient rites of the condoling council"; ratiyats means "they call, they name". Literally Van Loon's phrase means "ancient matter [by which] they condole, they call it". ${ }^{49}$

49 We would like to thank Roy Wright for the references. See The Iroquois Book of Rites, Horatio Hale (ed.) with an introduction by William N. Fenton, Toronto 1963, pp. 116-7, 208. Note that Van Loon also borrowed from Hale's work the names of the four Iroquois chiefs who signed the Tawagonshi treaty (pp. 118, 120). Cf. Gehring and Starna, "Revisiting the fake Tawagonshi Treaty of 1613 ", p. 10on. 


\section{Appendix 1. The Oldest Transcript of the Tawagonshi Treaty}

The oldest transcript (Transcript A) dates from 1959, when the text was sent to the Chief Archivist of the Dutch National Archives, Herman Hardenberg. Hardenberg's handwritten corrections and enhancements are added between square brackets (the numbers in the text indicate variants found in other transcripts, see Appendix 3 below): 50

Hier op Tawagonshi vergader[e] $\mathrm{t}^{1}$ met ons onderschreevenen ${ }^{2}$ [-en crossed out] Jakob Eelckens ${ }^{3}$ ende Hendrick Christiaenssen per breva geauthoriseert ende gelast de handel met de wilden ${ }^{4}$ inwoonders eyghenaers ${ }^{5}$ ofte beheerschers van $t^{\prime}$ landt hierontrent ${ }^{6}$ [hieromtrent] overna te gaen ende insoverre het Compatibel met $\operatorname{den}^{7}$ hierna volgende sal sijn $^{8}$ tot besluyt ${ }^{9}$ te coomen den Royaners ${ }^{10}$ der Rotinonghsiyonni ${ }^{11}$ Garhat Jannie, Caghneghsattakegh $^{12}$, Otskwirakerongh ${ }^{13}$ ende $^{14}$ Teyoghswegengh alsmeede andere mindere overste derselve die verclaeren ${ }^{15}$ dat sy alles daeraen gaende [...aende; first letter damaged] overeengecoomen sijn ${ }^{16}$, ende wy Participanten ${ }^{17}$ belooven ${ }^{18}$ : 1: Dat de handel tusschen ${ }^{19}$ hun volck ende die van ons sal toegelaeten worden soolangh wy Participanten oock ${ }^{20}$ weedersijdts ${ }^{21}$ g'accordeerdt ${ }^{22}$ sijn $^{23}$ ende verder 2: Dat wy Participanten de voorreght ${ }^{24}$ sullen hebben ${ }^{25}$ ons goederen uyt de neeringh ${ }^{26}$ weg te brengen ${ }^{27}$, midts dat eenighe Coopverdragh ${ }^{28}$ aengaende deselve nogh niet afgesproocken ${ }^{29}$ wierde $^{30}$ : ende verder 3 : Grondtstucken ${ }^{31}$ sullen connen gecoft worden van $t^{\prime}$ landt [dat] $\mathrm{wy}^{32}$ wilden Participanten als eyghen ${ }^{33}$ gebiedt beschouwen, midts dat er over gesproocken ${ }^{34}$ wordt door de individueelen ${ }^{35}$ ende een weedersijdts ${ }^{36}$ geschickt Coopverdragh opgemaeckt wordt: ende ${ }^{37}$ verder 4: Dat wy Participanten ons sullen behouden in geval van gebreck ${ }^{38}$ aen voedsel die niet en toereycken sal elckander aen den noodigheden te helpen ${ }^{39}$ : ende verder: 5 : In casa van meeningverschil ${ }^{40}$ betreffende louter ofte verbeelde onreghtvaerdigheden ${ }^{41}$ belooven wy Participanten dat deese als Auspicia Melioris Aevi zal blijven ${ }^{42}$ staen ende dat eenighe meeningverschil ${ }^{43}$ van welcke aerdt ofte oorsprongh dan oock ${ }^{44}$ voor een vergaderingh Commissarissen sal moeten ${ }^{45}$ gebraght worden om het alles te ondersoecken ${ }^{46}$.

Dit bovenstaende belooven ${ }^{47}$ wy Participanten weedersijdts ${ }^{48}$ in Amitie ende vriendtschap vol te houden ende te handthaven voor soolangh ${ }^{49} t^{\prime}$ gras groen is ende als een bewijs van Eere ende Toegeneeghenheydt ${ }^{50}$ verruylen $^{51}$ wy eene silver ketting ${ }^{52}$ voor een vaedem ${ }^{53}$ Seewant: Ende kenniss ${ }^{54}$ der waerheydt deeses onderteekent door den Participanten op deese 21 Aprill $^{55} 1613$.

50 Hardenberg also added punctuation, stating: "the punctuation has been indicated according to the general conventions". We have ignored this, as well as the normalization in capital letters that Hardenberg applied (he only wrote a capital at the beginning of a sentence, contrary to what is used in the original text). 
Jakob Eelckens ${ }^{56}$

Hendrich ${ }^{58}$ Christiaenssen
Garhat Jannie ${ }^{57}$

Caghneghsattakegh Otskwirakerongh ${ }^{59}$

Teyoghswegengh t' merck van -

t' merck van -

t' merck van -

t' merck van - 


\section{Appendix 2. Translation of the Tawagonshi Treaty}

This is the English translation published by Van Loon in 1968. In their 1987 article, Gehring, Starna, and Fenton included an English translation showing several deviations from that of Van Loon, although there are no crucial differences. These deviations are added between square brackets. ${ }^{51}$

Here at Tawagonshi met with us [Met with us here at T.] the undersigned Jacob Eelckens and Hendrick Christiaenssen, authorized by letter and obligated to examine into [ordered to investigate] the trade with the aboriginal [native] owners or directors [rulers] of the country hereabouts [,] and to conclude, so far as it may be compatible with the following the chiefs [sachems] of the Long House, Gerhatjannie [GarhatJannie,] Caghneghsattakegh, Otskwiragerough [Otskwiragerongh], and Teyoghswegengh, as well as [with] other lesser chiefs of the same [,] who declare that they are all [all are] in agreement thereupon [thereon], and we the participants [we, participants,] promise:

1, That trade between their people and ours shall be permitted as long as we the participants [we, participants,] are bilaterally agreed [also in mutual agreement], and further;

2, That we the participants [we, participants, ] shall have the privilege of bringing our goods out of [insert: the] trade channels [routes] as long as [provided that] no purchase agreement concerning them has [insert: yet] been made: and further;

3, Parcels of land may be purchased that we [,] the aboriginal [native] participants [,] consider as our property [own territory,] so long as [provided that] it is discussed by the individuals and a bilaterally [mutually] agreeable purchase agreement concerning them [last two words striked out] has been made, and further;

4, That we the participants [we, participants,] shall be obliged [continue] to help each other [one another] to [with] necessities in case of shortage of food that is insufficient, and further;

5, In case of a difference of opinion concerning [disputes relating to] real or imaginary [imagined] injustices we the participants [we, participants, ] promise that this will stand [shall serve] as an Auspicia Melioris Aevi and that any difference [dispute] from whatever nature or origin must [insert: then] be brought before a meeting [board] of Commissaries [magistrates] in order to examine the whole [investigate everything].

This foregoing [aforementioned] we the participants [we, participants, promise[,] in love [amity] and friendship[,] to continue [sustain] and to [striked out] maintain for as long as [the] grass is green[;] and as evidence

\footnotetext{
${ }^{51}$ Venables, "An analysis", gives as the appendix a "Translation by Dutch friends of the Onondogas"; as this is not a literal but a free translation, we will not discuss it here.
} 
[a token] of the [striked out] honor and goodwill [affection] we exchange a silver chain for a fathom of beadwork [wampum]; and knowledge [as acknowledgment] of the truth of this[,] here undersigned [it has been signed] by the participants on this 21st [of] April 1613.

(Signatures)

(totems)

We note that Neeringh is wrongly translated as "trade channels" or "routes"; this should read "trade area". 
34 H. Hermkens et al. / Journal of Early American History 3 (2013) 9-42

Appendix 3. Overview of Text Variants in the Different Transcripts of the Tawagonshi Treaty

The numbers in the lefthand column refer to the oldest transcript, as given in Appendix 1. Sporadic differences in initial capitalization (i.e. casa or Casa) have been ignored. 


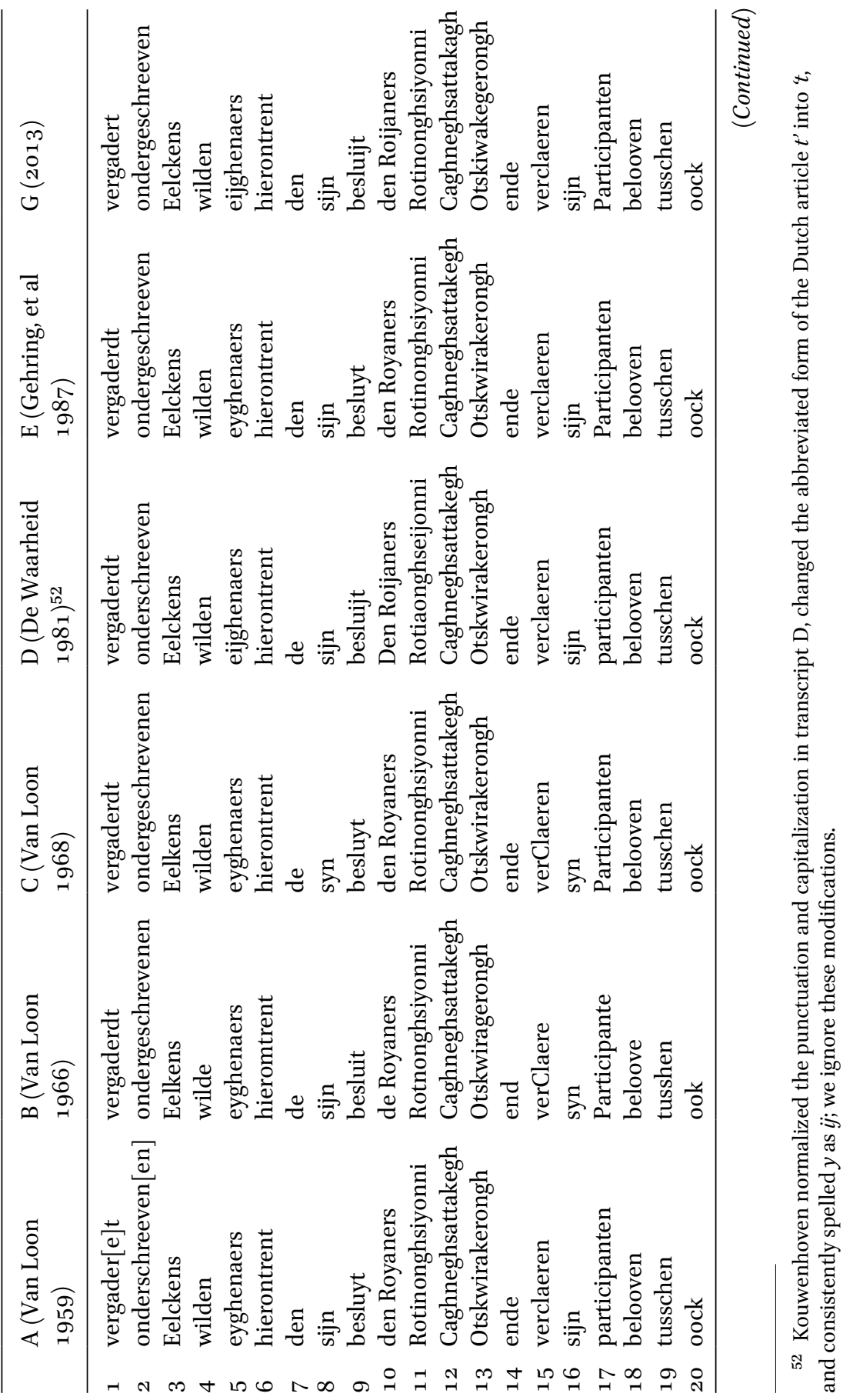




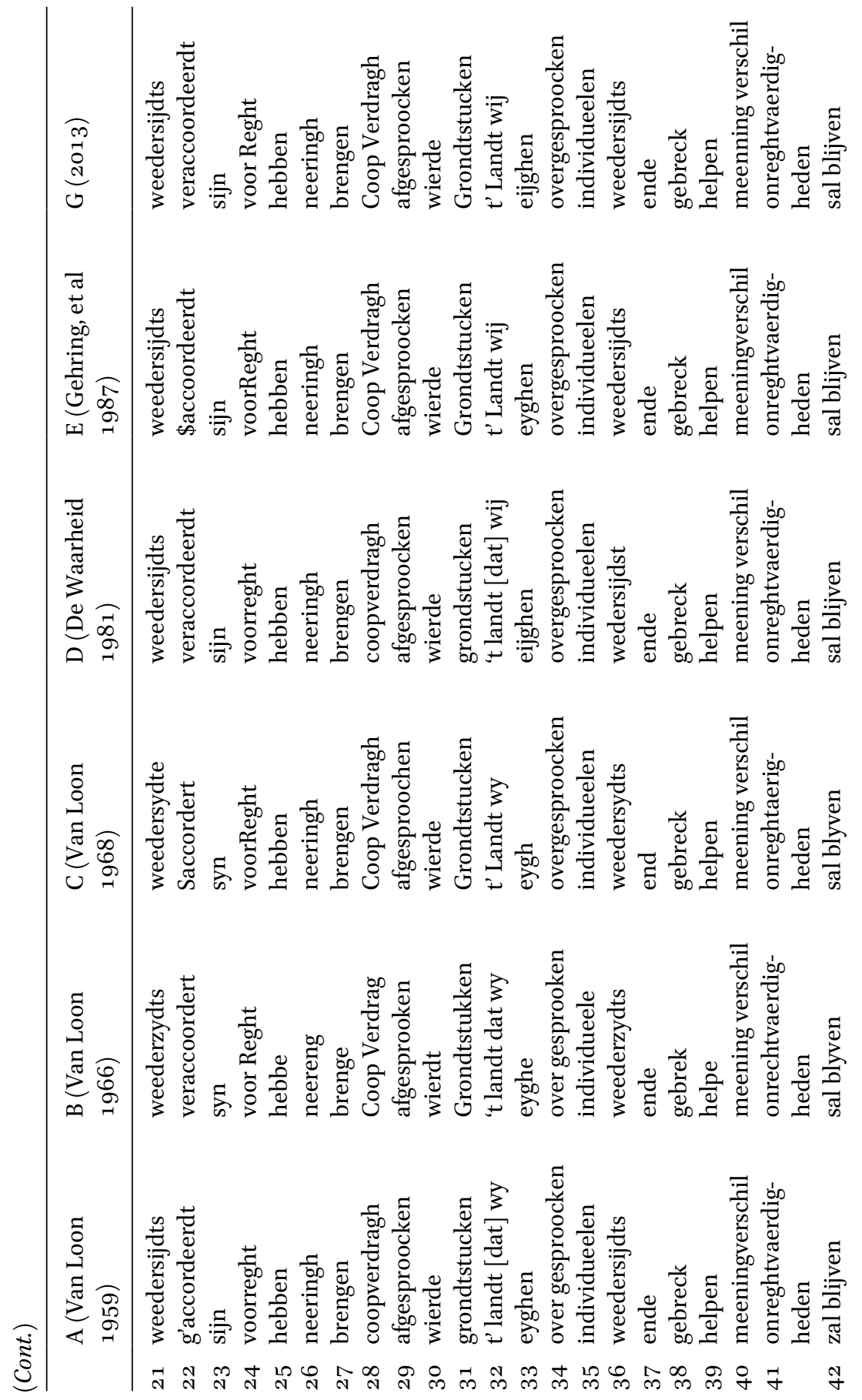




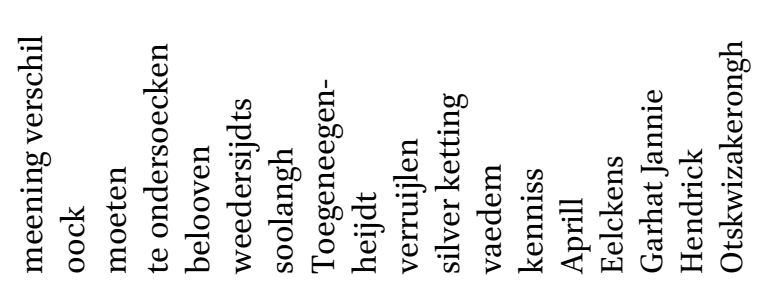

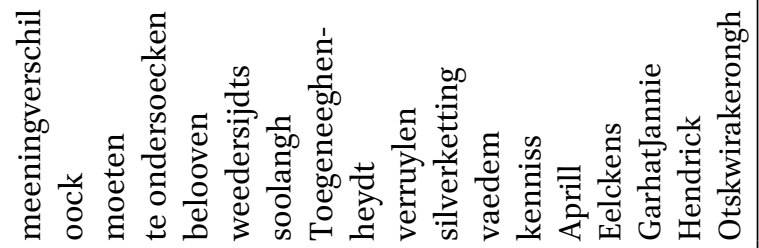

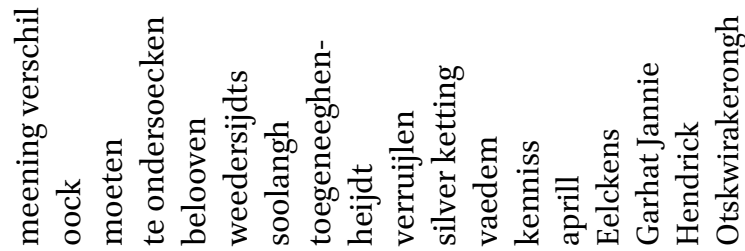

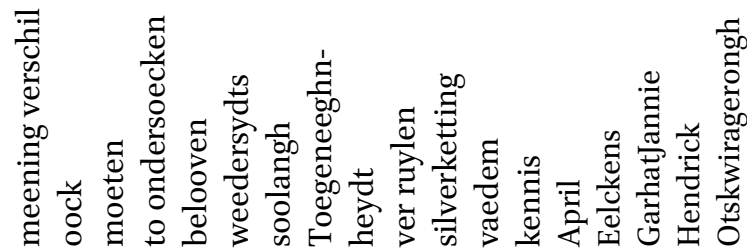

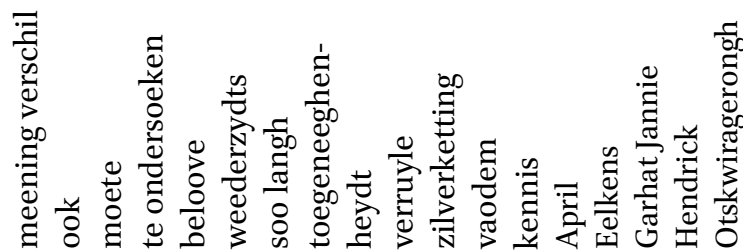

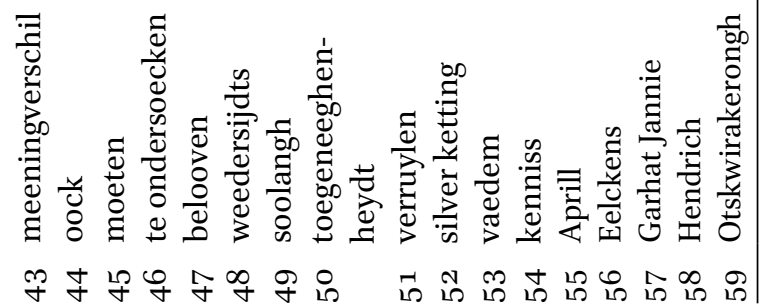




\section{Appendix 4. Forms or meanings unusual or unknown in seventeenth- century Dutch}

Archaic forms and typical written language forms

* ende "and": in the seventeenth century ende was used, but considered archaic; the generally used form was en - that is also how the form was pronounced.

* the plural form of substantivized adjectives wilden "wilde" and individueelen "individual" is formal, written language: in the spoken language of the seventeenth century, the - $n$ was not pronounced except in the case of a hiatus and most authors, even educated ones, left out the $-n$. On the other hand, in the treaty text is also mentioned the form overste "chiefs" (in: andere mindere overste "other lesser chiefs"), while the grammatically correct form would be oversten.

* the oblique case den "the" is written language for colloquial speech de.

* met den hierna volgende ... den Roijaners "with the following... chiefs": an abnormal construction, before Roijaners the word met "with", is likely to have been omitted; den in met den hierna volgende could be a dative neuter, this is an archaic form.

* the double negative in die niet en toereycken sal "that is insufficient" is archaic.

*aen den noodigheden "with necessities": archaic dative plural.

Mistakes in gender

* de voor Reght "the privilege": the use of article de "the" instead of het is noticeable, as it does not correspond with Dutch, but does so with Low Dutch and English. The space between the two parts of the compound (voor and reght) and the fact that Reght is capitalized could be anglicisms.

* ons goederen "our goods": should be onse goederen (in the Brabant dialect of the seventeenth century ons was correct).

* eenighe Coop Verdragh "any purchase agreement": should be eenigh.

* voedsel die "food that": should be: voedsel dat.

* eenighe meening verschil "any dispute": should be: eenigh.

Other grammatical mistakes

* ondergeschreeven "undersigned": encountered several times in the eighteenth century (WNT), and once in 1674 (Kronos), the usual form was ondergeschrevenen or onderschrevenen.

* daeraen gaende "thereupon": not found in the WNT, only dienaangaande. 
* ende kenniss der waerheydt "and knowledge of the truth": should be ende tot/als kenniss der waerheydt "and as knowledge of the truth", or in/ter kennisse der waerheydt "in knowledge of the truth".

\section{Anglicisms}

* Compatibel "compatible": this French loan is not found in Dutch before 1650,53 and must here be an anglicism.

* tot besluijt te coomen "to conclude": this combination does not occur in the seventeenth century; tot besluijt only means "lastly, finally", tot het/een besluit komen (with obligatory article het "the" or een "a") is not encountered until the eighteenth century; tot besluijt te coomen appears to be an anglicism, a translation of to come to a decision.

* Participanten "participants": this French loan has been in use in Dutch since the establishment of the Dutch East India Company in 1602 with the specific sense of "shareholders"; the sense "participants" is not known in Dutch before the twentieth century; in the treaty this meaning is most probably an anglicism.

" $t$ ' Landt wij ... beschouwen "the land we consider": the omission of the relative pronoun is an anglicism; the correct Dutch form is t' Landt dat wij beschouwen "the land that we consider".

* individueelen "individuals": the adjective individueel was not borrowed from the French until the eighteenth century, and only later it came to be used as a noun; individueelen is an anglicism here (note that according to the OED individual in this sense in English is found only since 1626).

* in casa van "in case of": must be an anglicism, based on the English "in case of", which, according to the OED, has been present in English only since 1736 .

* meening verschil "difference of opinion": me(e)ning in seventeenthcentury Dutch stands for "intention"; the combination meening verschil must be an anglicism; the Dutch language only features meningsverschil (with linking -s-), which was not found until the nineteenth century, and was regarded as a germanism at the time (WNT).

* Auspicia melioris aevi ("tokens of a better age"): this expression is found in neither old nor modern Dutch. However, it is, with singular auspicium, found in modern English dictionaries, ${ }^{54}$ because it has been the motto of the English Order of St. Michael and St. George since 1818. The maxim is not

53 Van der Sijs, Chronologisch woordenboek.

54 Gehring, Starna, and Fenton, “The Tawagonshi Treaty of 1613", p. 380. 
Classical Latin, and it is probable that it became known as the motto of the Duke of St. Albans, a title that was created by King Charles II in 1683/4.

* Amitie "friendship": the French amitié was not found in Dutch texts until the beginning of the eighteenth century; there is no doubt that the tautological expression Amitie ende vriendschap "amity and friendship" is an anglicism, in imitation of the Treaty of Amity and Friendship, signed by the English Quaker William Penn and the Lenape Indians in 1682.

* voor soolangh t' gras groen is "for as long as the grass is green": the entire expression must be an anglicism: voor soolangh does not occur in seventeenth-century Dutch; Gehring et al. write about the green grass: "[it] is a metaphor familiar to present-day Americans from film and fiction but is not a seventeenth-century form". 55 The expression may be inspired by the older combination "so long as grass shall grow or waters run", renowned from negotiations that led to the Treaty of Fort Stanwix $(1784)^{56}$ and from a quotation from Andrew Jackson, seventh president of the United States, who wrote in 1829 to the Creek Nation that they could live beyond the great river Mississippi "as long as the grass grows or the water runs, in peace and plenty".

* bewijs van Eere "mark of honor": not a Dutch expression, the standard word was and still is eerbewijs. The former appears to be an anglicism.

* verruijlen voor "to exchange for": in the seventeenth century one said verruijlen aen or om; voor is eighteenth-century Dutch and modern Dutch, and here it is probably an anglicism.

* silver ketting "silver chain": this is an anglicism, the Dutch seventeenthcentury form was silvere $(n)$ ketting. ${ }^{57}$

Anachronistic words, forms or expressions

* overna te gaen "to examine into": this combination of words does not occur in seventeenth-century or modern Dutch; nagaan "to check", is seventeenth-century Dutch. Perhaps this combination stems from Low Dutch?

55 Gehring, Starna, and Fenton, "The Tawagonshi Treaty of 1613", p. 385; Benjamin, "Tawagonshi Agreement", p. 12, contests this, which was refuted in Gehring and Starna, "Revisiting the Fake Tawagonshi Treaty of 1613", pp. 100-1.

56 E.B. O'Callaghan (ed.), Documents Relative to the Colonial History of the State of New York, 15 vols. (Albany, 1854-83), 8:118, 128.

57 Gehring and Starna, "Revisiting the Fake Tawagonshi Treaty of 1613", p. 97, furthermore point out the anachronistic metaphor "silver ketting" - a symbolic iron chain was not known to the Mohawk until around 1645 , a silver chain not until the 1670 . See the contribution of Jon Parmenter in this issue. 
* hun volck ende die van ons "their people and ours": the combination of die van ons in the sense of "ours" is modern Dutch.

* Coop Verdragh "purchase agreement": this compound is not found before the eighteenth century; in the seventeenth century coop cedul and coop brief were used.

* als eijghen gebiedt beschouwen "consider as our territory": the word combination of beschouwen and als did not occur in Dutch until the eighteenth century; in the seventeenth century beschouwen only had the literal meaning "look (at), examine".

* gebreck aan voedsel "shortage of food": in seventeenth-century Dutch gebrek was used in combination with a genitive or with van; gebrek aan is modern Dutch.

* betreffende "concerning": this preposition was not found until the end of the eighteenth century. ${ }^{58}$

*van welcke aerdt ofte oorsprongh dan oock "whatever nature or origin": this expression with van welke... dan ook, did not exist in the seventeenth century.

* Toegeneeghenheijdt "affection": in seventeenth-century texts only forms with - $t$ - (toegeneeghentheijdt) are found.

* per breva "by letter": per breva is not Latin; only in vulgar Latin breve came to mean "letter"; this breve was borrowed into English and used for "official letter, charter", later predominantly "a papal letter". The word also occurs in Dutch, but only from the eighteenth century onwards (and in the early Middle Ages as a variant of brief "letter"); the combination per breve occurs in neither Late Latin, nor in English or Dutch.

" seewant "wampum": the word stems from Pidgin Delaware, a contact language which originates from the 1620 s, so it could not have been borrowed by Dutch before that time. ${ }^{59}$

\section{Anachronistic meanings}

* insoverre "so far as": in the seventeenth century this meant "if, in case that"; the sense "to the extent that" is modern Dutch or an anglicism.

* afgesproocken "agreed upon": the word did not occur in this sense in the seventeenth century (it only meant "having talked someone out of something" and "finished speaking" at that time).

\footnotetext{
58 Van der Sijs, Chronologisch woordenboek.

59 Gehring and Starna, "Revisiting the Fake Tawagonshi Treaty of 1613", p. 97.
} 
* Grondtstucken "parcels of land": in the seventeenth century only in the sense of "main points, doctrines"; according to the WNT, the sense of "parcel" is a nineteenth-century germanism.

* geschickt "agreeable": in the seventeenth century this was only used with reference to persons; with reference to things it was not used until the eighteenth century, and then always followed by voor, tot, te (WNT), which was dropped only in the nineteenth century, or om (WNT); the present meaning stems from the nineteenth century. (If geschickt is meant as past particle of schicken, the construction weedersijdts geschickt Coop Verdragh can be translated as "a bilaterally negotiated purchase"; this construction is conceivable in the seventeenth century, but Coop Verdragh was not used in that century.)

* opgemaeckt "has been made": in the seventeenth century this was not associated with verdrag "treaty".

* dat wy ons sullen behouden "that we shall be obliged": this meaning occurs neither in older nor in modern Dutch.

* louter "real" meant and still means "pure, clear" in Dutch; the sense "real" does not occur in Dutch.

* blijven staen "stand": this meaning is not found in the seventeenth century.

*volhouden "maintain": this meaning has been known only since the eighteenth century. 